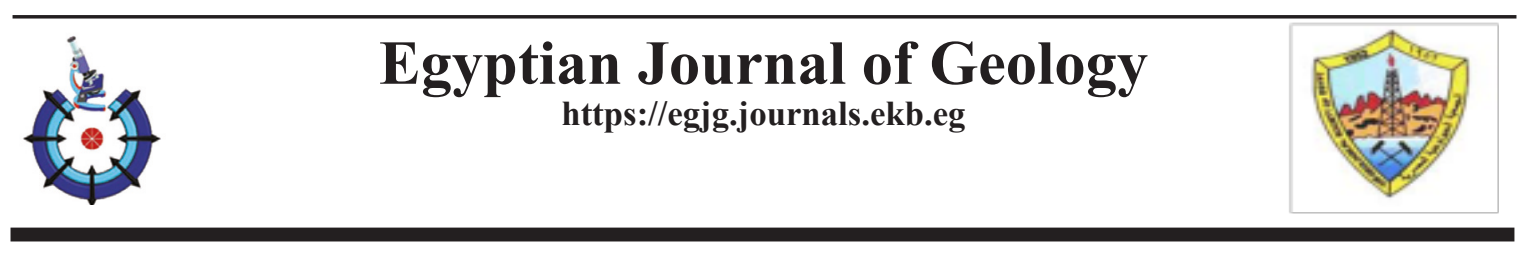

\title{
Hydrogeological Characteristics of the North Eastern Part of El Farafra Oasis, Western Desert, Egypt
}

\author{
El-Ghamrawy, Mohamed Magdy ${ }^{(1) *}$, Ali, Ali Abdel-Motelib ${ }^{(2)}$, Fikry, Akram Mohamed ${ }^{(1)}$, \\ and Abu Salem, Hend Saeed ${ }^{(2)}$ \\ (1) Research Institute for Groundwater, National Water Research Center, El-Kanater El-Khairiya, \\ Egypt \\ ${ }^{(2)}$ Geology Department, Science Faculty, Cairo University, Giza, Egypt
}

\begin{abstract}
$\mathbf{T}$ HE EGYPTIAN Western Desert is considered as one of the most arid regions in the country. Recently, expanding developmental activities are invading the study area in El Farafra Oasis especially agriculture. The groundwater in the Western Desert represents the main source of water where the increase in groundwater extraction rates could affect the future development plans negatively. Accordingly, this article is concerned with the study of the hydrogeological characteristics of the Nubian Sandstone Aquifer System (NSAS) and the effect of groundwater exploitation on aquifer potentiality. The study includes well inventory, measuring piezometric heads, measuring salinity of groundwater samples as well as conducting and analysing of pumping/ recovery tests on selected wells. Two hydrogeological cross sections were constructed based on the data of new drilled wells. The regional groundwater flow direction in the NSAS is from southwest to northeast. However, local groundwater flow from east to west is evidenced due to extensive groundwater extraction in the west. The analyses of pumping tests were carried out to estimate the hydraulic properties such as the hydraulic conductivity (K), the transmissivity $(\mathrm{T})$ and the storativity $(\mathrm{S})$. The average $\mathrm{K}$ is about $7.1 \mathrm{~m} / \mathrm{d}$, while the average $\mathrm{T}$ is about $2704 \mathrm{~m}^{2} / \mathrm{d}$. The storativity reached about 0.0002 . The potentiality of the NSAS varies from high potential in the middle and the eastern parts, to moderate potential in the western parts. A groundwater development plan is recommended to avoid the deterioration of the NSAS in the coming decades.
\end{abstract}

Keywords: El Farafra Oasis, Nubian Sandstone Aquifer System, Hydrogeological settings, Egypt.

\section{Introduction}

In arid and semi-arid areas, groundwater serves as a substantial part of the total water resources used for drinking and irrigation purposes (Wang \& Cheng, 1999; Llamas \& Martinez-Santos, 2005; Re \& Zuppi, 2011; Keesari, 2014). In the past few years, an increase of groundwater usage due to expansion in development activities took place because of increased population as well as water scarcity (Omar \& Moussa, 2016; Clemens et al., 2020). The study of the aquifer system characteristics is crucial for water management plans in terms of water quality and quantity. The study area in El Farafra depression belongs to the New Valley Governorate which represents about $44 \%$ of the area of Egypt (official website of New Valley governorate). The main water resources in El Farafra area are springs as well as shallow and deep production wells which were used in development of these areas several years ago. Accordingly, this study deals with the hydrogeological characteristics of the Nubian Sandstone Aquifer System (NSAS) and their

Corresponding author: El-Ghamrawy, Mohamed Magdy, Email: mohamed.mmg191@gmail.com

Received: 06/10/2021; Accepted: 31/10/2021

DOI: 10.21608/egjg.2021.99109.1007

(C)2021 National Information and Documentation Center (NIDOC) 
possible changes as a consequence of the increase in groundwater exploitation in some localities within El Farafra Oasis.

\section{Location}

El Farafra Oasis lies in the middle of the Egyptian Western Desert, where it is bounded from northeast by El Bahariya Oasis and from southeast by El Dakhla Oasis with an area of about 86,200 km² (E1 Sheikh, 2015). The selected subareas extend from west to east as follows: Lowa Sobieh, Abu El Nuss, Qasr El Farafra, Sahl Baraka, and Sahl Qaraween. The study area lies between latitudes $26^{\circ} 59^{\prime}, 27^{\circ} 14^{\prime}$ and longitudes $27^{\circ} 49^{\prime}, 28^{\circ} 37^{\prime}$ with total area of about $2212 \mathrm{~km}^{2}$ (Fig. 1).

\section{Geomorphology}

El Farafra Depression is a semi closed basin bounded by escarpments from different directions. Topographically, the ground elevation in El Farafra Oasis varies from 50 to $150 \mathrm{~m}$ (above mean sea level) including some hills, such as: Gebel Gunna El Bahary and Gebel Gunna El Qebly. Generally, the geomorphic units in the study area could be subdivided into five units as follows (Fig. 2):

(i) The Depressions: cover most of the study area that is filled by sand dunes and sand sheets.
It consists of playa deposits distributed at the foot slopes of the eastern escarpment of El Quss Abu Said Plateau, in the center of the depression, east of Gebel Gunna El-Bahary. The White Desert (also called the White Sahara) is located in the northern part of El Farafra depression.

(ii) El Farafra Plateaus: Three major plateaus are found in El Farafra Oasis including the Nagb Plateau (200 m a.s.l.) at the north and northeast, El Quss Abu Said Plateau (325 m a.s.l.) at the west, and the Kharafish Plateau (400 $\mathrm{m}$ a.s.1.) at the southeast (Ali, 2004).

iii) The Scarps: are represented by the boundaries of the three plateaus in El Farafra Oasis.

(iv) Pediments: represent the foot of scarps of a moderate height, where they are found in the domain around the Minqar Depression which is located to the southwest of the study area and at Sahl Qaraween area (Ali, 2004).

and (v) Sand dunes and sand sheets: cover most of the study area and extends west, east and northwards.

\section{Geological setting}

Surface geology of El Farafra Oasis

The surface geology of El Farafra Oasis in the study area is represented by several formations

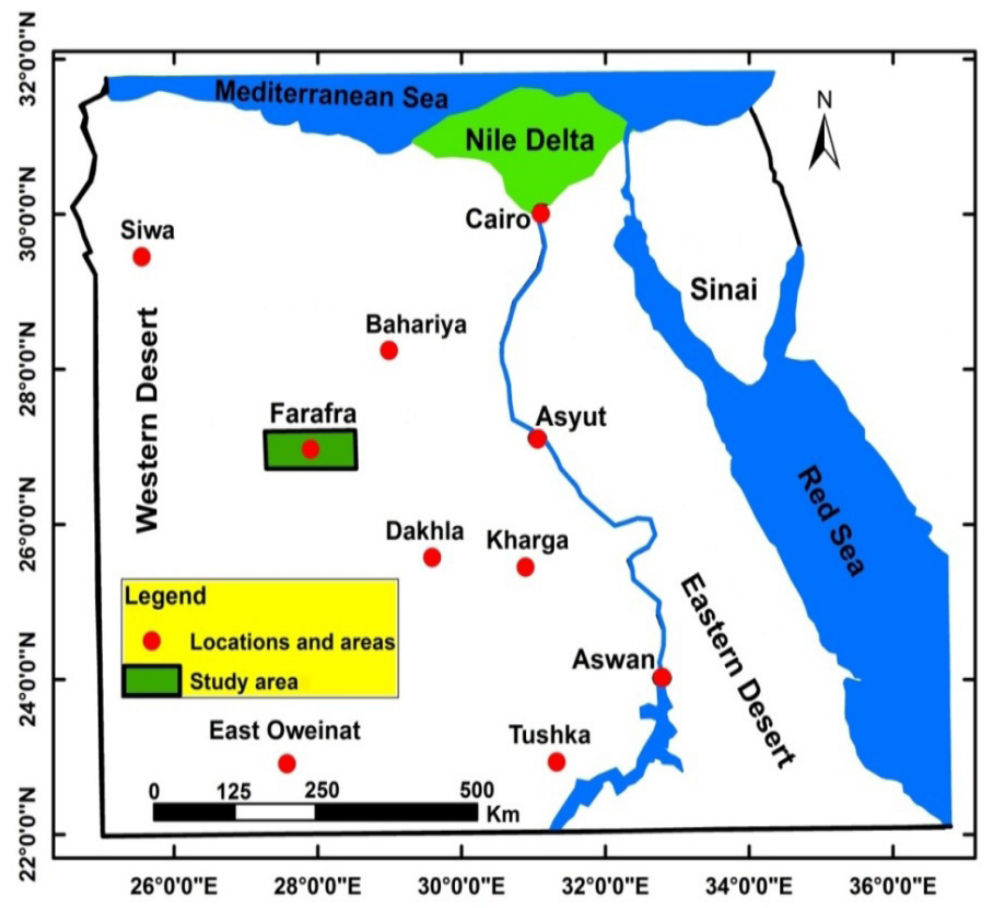

Fig. 1. Location map of study area in El Farafra Oasis. 


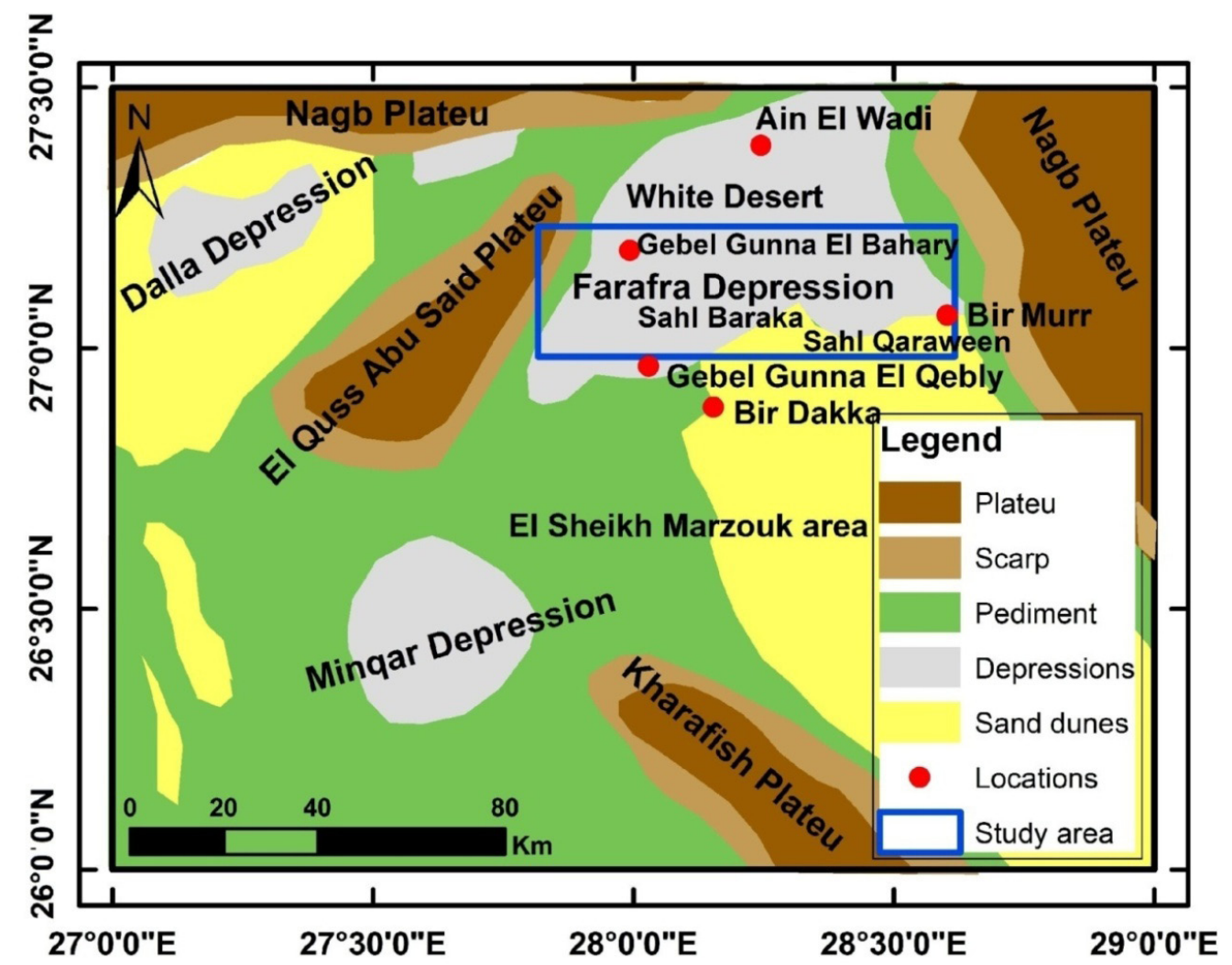

Fig. 2. General geomorphic features of EI Farafra Depression and its surroundings (after Ali, 2004).

ranging from Quaternary to Upper Cretaceous. The rock units exposed in El Farafra area are presented on the geologic map of CONOCO Coral (1987). According to CONOCO Coral (1987), Nassar (2005) and Ali (2004), these rock units are differentiated stratigraphically from top to base as follows (Fig. 3):

\section{Quaternary deposits}

The Quaternary deposits at the surface of the study area are composed of sand dunes, sand sheets and playa deposits, and belong to Pleistocene to Holocene age.

\section{Tertiary deposits}

Presented by the following formations:

Nagb Limestone Formation (Tetn); varies in age from Lower to Middle Eocene. It is found in the northern and northeastern boundary of El Farafra Oasis at Nagb Plateau. It is not exposed on the surface of the study area.

Farafra Limestone Formation (Tetf); is exposed on the surface at El Quss Abu Said Plateau and mainly consists of thick fossiliferous lagoonal limestone belongs to Lower Eocene with an average thickness of $69 \mathrm{~m}$.
Garra Formation (Tpg); is represented by chalky limestone with shale and marl intercalations. It is not exposed in the study area, but it has exposure at the scarp and pediment of Kharafish plateau.

Esna Shale Formation (Tpe); belongs to Paleocene and composed of deep marine shale. It is found at the scarp slopes surrounding the plateaus in El Farafra area, its average thickness varies from 70 to $176 \mathrm{~m}$.

Tarawan Chalk Formation (Tpt); it is found at the pediment of El Quss Abu Said Plateau and to the southwest from this plateau and is characterized by creamy color chalky limestone beds. Its average thickness reaches 505m (Abdel Aziz, 1968).

\section{Mesozoic (Upper Cretaceous) deposits}

Presented by the following formations:

Dakhla Formation (Kud); is represented by dark color shale that belongs to the Maastrichtian age. It is only exposed in the middle and southeast of El Farafra Oasis.

Khoman Chalk Formation (Kuk); is exposed at the surface in the middle, north and northeast 
of El Farafra Oasis. Its age ranges from Late Campanian to Lower Maastrichtian. It is found in the depression floor and the slopes of the isolated hills (Salem, 2002). The thickness of this formation may reach about $160 \mathrm{~m}$ in the subsurface (Barakat \& Abdel Hamid, 1974).

El Hefhuf Formation (Kuh); is represented by shaley and sandstone succession of shallow marine environment that belong to Campanian age. It is exposed on the northern part of El Farafra Oasis. It is overlain by Khoman Chalk Formation, while it is underlain unconformably by Wadi Hennis Formation (Hamad, 2004).

Wadi Hennis Formation (Kun); is represented by sand and clay sediments that belong to Campanian age. It is exposed at the north of El Farafra Oasis.

\section{Subsurface geology}

The subsurface geologic formations vary from Upper Cretaceous to Pre-Cambrian (which represents the basement rocks). These formations are arranged from top to bottom as follows:

El Heiz Formation (Kuz); belongs to Late Cenomanian and consists of dolomitic sandstone, siliceous dolostone and sandy clay. It is absent from the surface of the study area but appears on the surface due north direction outside El Farafra Oasis (CONOCO Coral, 1987).

Bahariya Formation (Kub); belongs to Cenomanian and consists of fluviatile sandstone, siltstone, and intercalations of shale.

Maghrabi Formation; El Shayeb et al. (2013) mentioned that the Maghrabi Formation belongs to Cenomanian age, where it consists of claystone with silt and sand. The lower surface of the previously mentioned Bahariya Formation represents the upper surface of the Maghrabi Formation. This formation represents an aquiclude in the Nubian System where it forms the aquiclude and the separator between "the Shallow Nubian Sandstone Aquifer" and "the Deep Nubian Sandstone Aquifer".

Sabaya Formation; this formation consists mainly of fluviatile clastic sandstone sediments ranging from fine to medium size and belongs to the Upper Cretaceous Period. This formation represents the upper productive part of the "Deep Nubian Aquifer". It is bounded from the bottom by Abu Ballas Formation.

Abu Ballas Formation; it is represented by
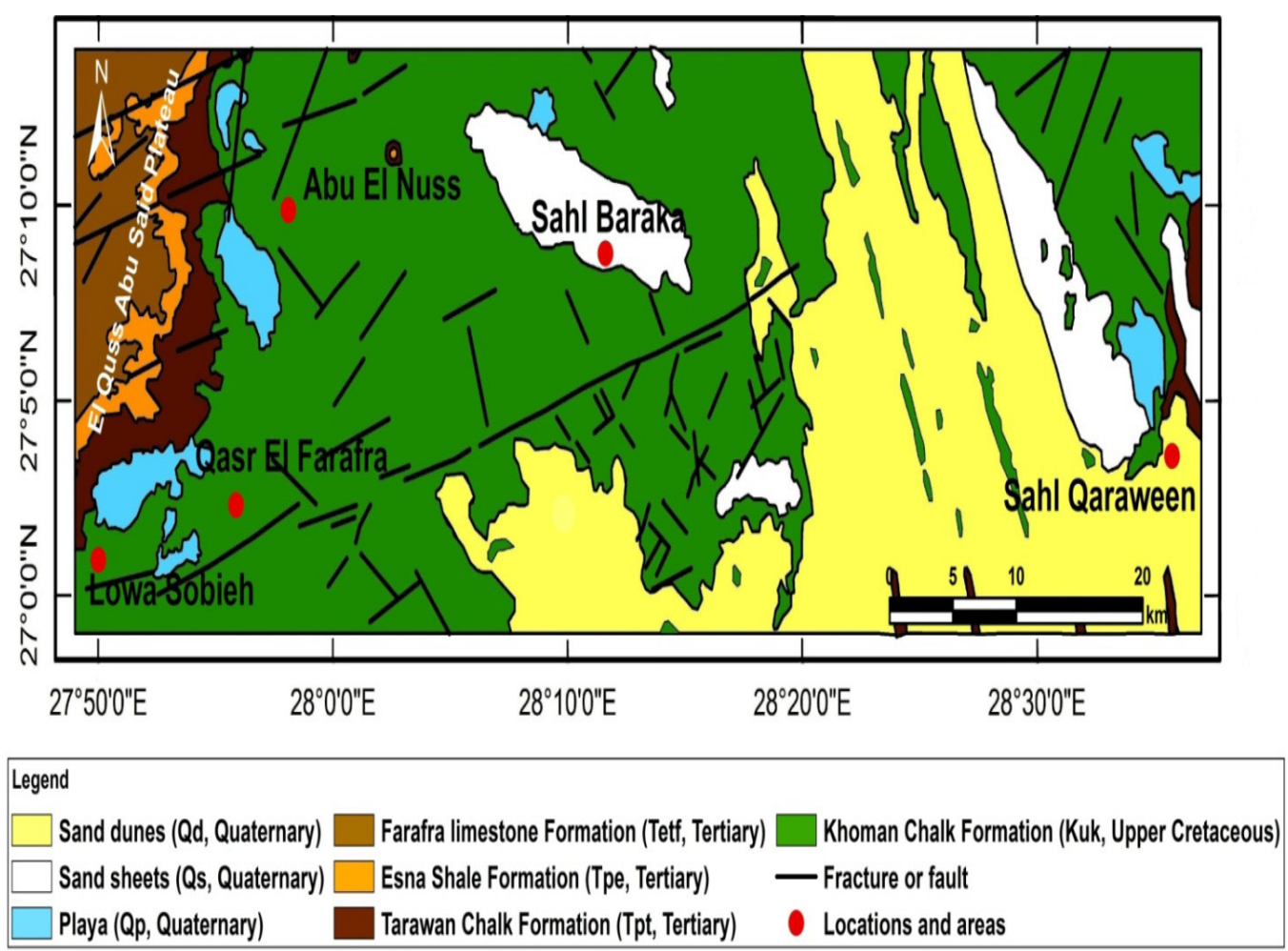

Fig. 3. Geologic map of the study area (after CONOCO Coral, 1987). 
shallow marine deltaic sediments of Aptian age (Klitzsch, 1978; Bottcher, 1982 and 1985; Schrank, 1982). These deposits include claystone, silt, and sand, and is underlain by the Six Hills Formation and is considered as an aquitard in the deep part of the NSAS.

Six Hills Formation; it underlies the Abu Ballas Formation and belongs to Late JurassicLower Cretaceous Periods (Klitzsch and LejalNicol, 1984). It consists of medium to coarse sandstone deposits and is classified as the main productive zone in the NSAS. Accordingly, this formation and the underlying unexplored sand units belonging to Paleozoic could be considered as the largest part in the NSAS due to the great thickness which may reach about $1000 \mathrm{~m}$.

Basement rocks: the basement relief is found at average level that reaches $\sim-1900 \mathrm{~m}(\mathrm{RIGW} /$ ASRT, 2016).

\section{Structural setting}

Based on the tectonic framework of the Western Desert, El Farafra area lies at the upthrown fault block of the Syrian Arc fold System in the Western Desert. Accordingly, the area was subjected to numerous tectonic events followed by several depositional settings during the previous eras leading to creation of hydrogeological blocks.

Anticlines, synclines, and faults represent the main structural features in El Farafra Oasis.
The study area includes El Maqfi anticline which passes through the western part from northeast to southwest and extends out of the study area. In the eastern part, Qur Hadid syncline passes where its direction extends from northeast to southwest. There are numerous faults found in the study area (Figure 4). All these structures could affect the groundwater occurrence within the study area.

\section{Hydrogeologic settings of the study area}

Two main aquifer systems constitute the groundwater regime within the study area namely, the Post Nubian Aquifer system (PNAS) and the Nubian Sandstone Aquifer System (NSAS). In the following a brief will be given upon these systems:

\section{Post Nubian Aquifer System (PNAS)}

The carbonate rocks, in the form of limestone, represent the PNAS which includes intercalations of shale in some parts and overlies the Nubian succession. The carbonate formations constituting this system are: Nagb Limestone (Lower-Middle Eocene), Farafra Limestone (Lower Eocene), Garra (Paleocene), Tarawan Chalk (Paleocene), and Khoman (Upper Cretaceous). Generally, the carbonate rocks should by fissured or fractured to be suitable for storage and transportation of groundwater. The source of recharge to this aquifer system is mainly through the vertical movement of groundwater from the underlying Nubian aquifer system through fractures and faults.

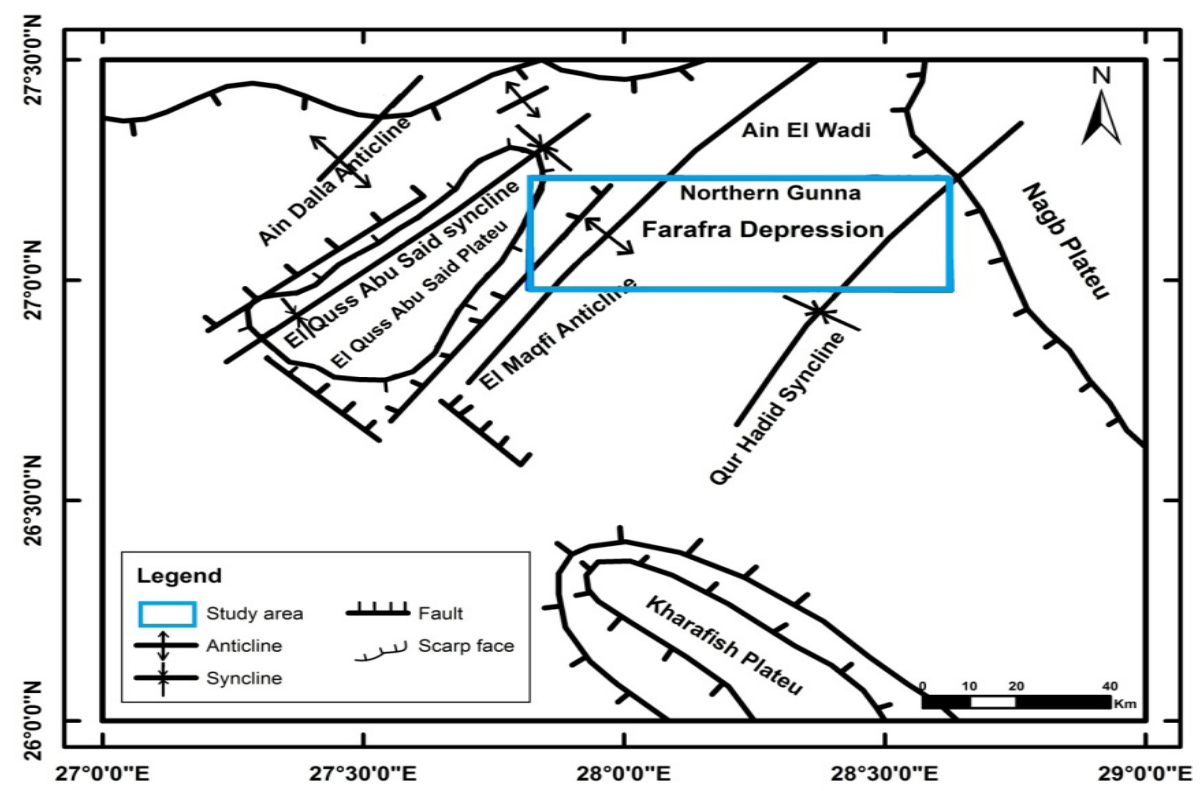

Fig. 4. Structural map of El Farafra area (after Ali, 2004). 
Nubian Sandstone Aquifer System (NSAS)

In the study area, the NSAS is divided into shallow and deep zones. It consists of Wadi Hennis, El-Heiz, Bahariya, Maghrabi, Sabaya, Abu Ballas, and Six Hills formations that constitute the major lithological units of the NSAS. This succession varies in thickness from 1827 to $1875 \mathrm{~m}$ with an average of about $1850 \mathrm{~m}$.

The regional groundwater flow direction in NSAS is from southwest to northeast. The recharge to this aquifer system is relatively limited, and it could be considered as a fossil water (non-renewable aquifer). The discharge takes place through springs and groundwater wells and increases with time due to the increased development activities.

\section{Methodology}

This study aims to assess the hydrogeological characteristics of the existing main aquifers in the study area using the collected data from the new drilled wells in years 2014,2015 and 2016. To achieve these goals, several sources were used including the geological map of El Farafra (CONOCO Coral, 1987), the previous hydrogeological cross sections especially from El Farafra-Bahariya hydrogeologic map of the Research Institute for Groundwater (RIGW/ASRT, 2016), data of water level measurements, well logs and the available description of the subsurface lithology and pumping tests data. The study includes among other activities, well inventory of the shallow and deep wells, measuring of water level and piezometric head, collection and analysing of groundwater samples as well as conducting and analysing of pumping/ recovery tests on some selected wells. Based on the collected and analysed data, a recent Piezometric head contour map and two hydrogeological cross sections were constructed

The piezometric head contour map was done using ArcGIS 10.2 software, while the hydrogeological cross sections were drawn using ground elevation data, lithological description, interpretation of the Gamma-Ray and electric logs followed by scanning and digitizing using ArcGIS 10.2 software. Additionally, the pumping tests results of seven wells were analysed using Aquifer Test software 2016.1 to estimate the hydraulic properties of the NSAS in the study area.

\section{Results and Discussion}

\section{Piezometric head contour map}

The piezometric head contour map was constructed according to the measured piezometric head obtained from thirty-one wells penetrating the Nubian aquifer in the study area. The total depth of the majority of these wells exceeds 500 m (Figure 5).

According to this map, the piezometric head in the study area ranges between $80 \mathrm{~m}$ and 120 $\mathrm{m}$ (above mean sea level), indicating that the groundwater flow direction is from east to west contrasting the known general groundwater flow direction of the NSAS in the Western Desert which is from southwest to northeast direction (Heinl and Brinkmann, 1989).

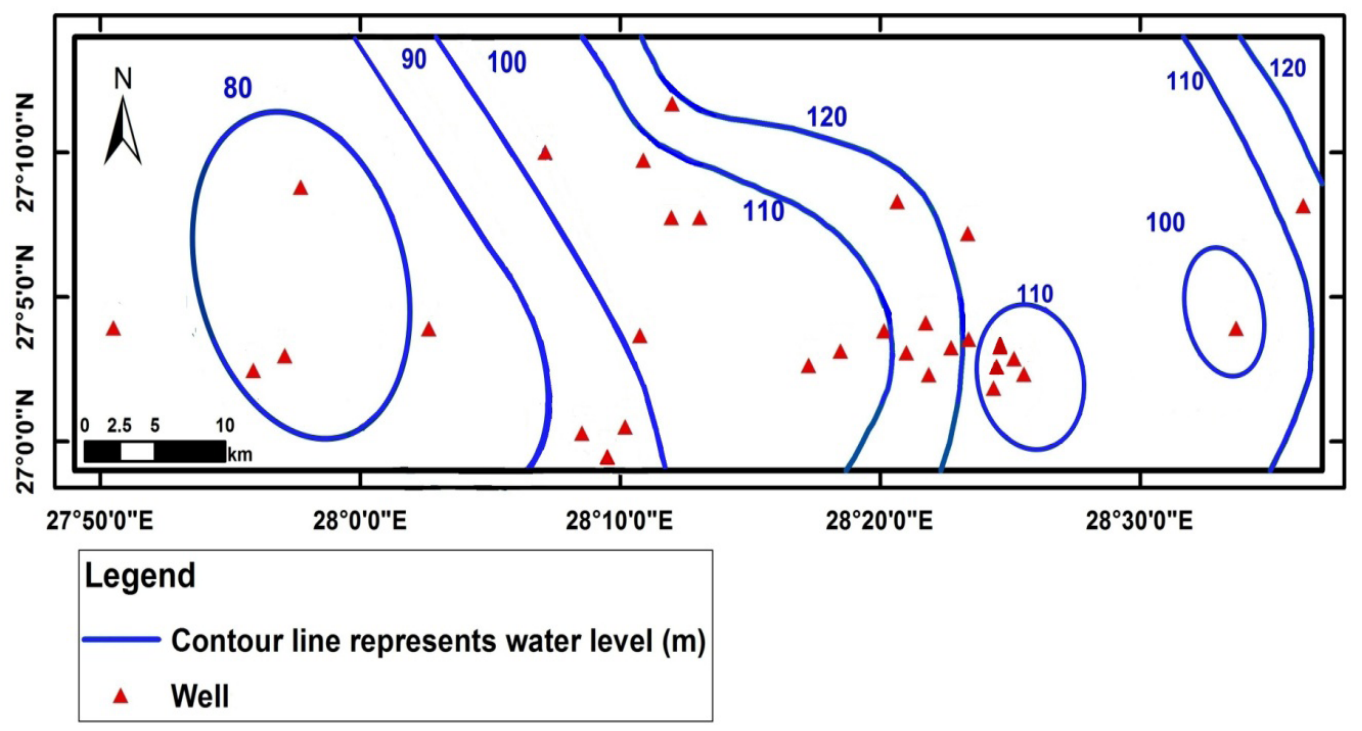

Fig. 5. The piezometric head map of the NSAS in the study area. 
To the west of the study area; especially at Lowa Sobieh, Abu El Nuss and Qasr El Farafra areas; the piezometric head values vary from +80 to $+100 \mathrm{~m}$, while to the east of the study area the piezometric head varies from +100 to +120 $\mathrm{m}$ (above mean sea level). The local variation of groundwater flow direction in the study area could be explained as a result of the local groundwater abstraction in some locations at the western part of the study area and related observed drawdown that induces local changes in groundwater flow direction. On the other hand, the higher groundwater levels in the middle and the eastern zones were due to the lower discharge rate at these areas. Additionally, local structures (such as faults) and the presence of shale intercalations could locally prevent the groundwater flow. According to RIGW/ASRT (2016), the drawdown reaches about one meter per year as result of extensive discharge rate, especially at Lowa Sobieh area.

\section{Hydrogeological cross sections}

In this work, the data of nine new drilled wells (drilled in the years 2014, 2015 and 2016), including electric well logs and subsurface cuttings, were used for the preparation of two hydrogeological cross sections (Figure 6a). Additionally, the hydrogeologic cross section of RIGW/ASRT (2016) was used to detect the basement level due to absence of drilled wells penetrating the basement in the study area.

An E-W cross section was prepared depending on the data of the wells; A, B, C, D, and E (Figure $6 b$ ), while a NE-SW cross section was based on the wells; F, B, G, H, and I (Figure 6c). All the used wells are penetrating the deep aquifer. From these two hydrogeological cross sections, the following information about the existing aquifer systems could be concluded:

\section{Post Nubian Sandstone Aquifer System:}

From the E-W hydrogeological cross section, the thickness of aquifer system reaches about 195, 202, 200, 175 and $205 \mathrm{~m}$ in wells A, B, C, D and $\mathrm{E}$; respectively, with average thickness of about $195 \mathrm{~m}$ (Figure 6b). In the NE-SW hydrogeological cross section, the thickness of this aquifer system is about 152, 202, 115, 200 and $185 \mathrm{~m}$ in wells F, $\mathrm{B}, \mathrm{G}, \mathrm{H}$ and I; respectively with average thickness of about $171 \mathrm{~m}$ (Figure 6c).

\section{Nubian Sandstone Aquifer System:}

From the E-W hydrogeological cross section (Fig. 6b), the shallow zone of this aquifer system consists of Wadi Hennis, El-Heiz and the
Bahariya formations, with thickness that varies from 40 to $140 \mathrm{~m}$ with an average thickness of 90 m. The Maghrabi clay Formation represents the first aquiclude in the Nubian system which varies in thickness from 50 to $150 \mathrm{~m}$ with average of about $100 \mathrm{~m}$. On the other hand, the deep aquifer is represented by the Sabaya, and the Six Hills formations with aquitard of Abu Ballas Formation that separates the two formations. The thickness of these units in addition to the unexplored part of the Devonian deposits varies from 1725 to 1800 $\mathrm{m}$ with an average thickness of about $1760 \mathrm{~m}$. The basement is found at levels from 1920 to 1940 $\mathrm{m}$. The water level changes from +80 to +120 $\mathrm{m}$ (above mean sea level). There are some faults in this hydrogeologic cross section indicating mixing between the groundwater of the different zones within the Nubian Sandstone succession.

In the NE-SW hydrogeological cross section (Figure 6c), the thickness of shallow Nubian aquifer including Wadi Hennis, El-Heiz and Bahariya Formations changes from 60 to 120 $\mathrm{m}$ with average value of $90 \mathrm{~m}$. The Maghrabi Formation represents the main aquiclude of thickness that varies from 30 to $160 \mathrm{~m}$ with averaging $95 \mathrm{~m}$. In addition, the deep succession of the Nubian system including the Sabaya, Abu Ballas, Six Hills Formations and Devonian units reached 1550-1600 m thickness. The basement is found at levels that vary from 1840 and 1860 $\mathrm{m}$. It is also expected that there is a hydraulic connection between the shallow and the deep zones through the existing fault planes.

\section{Groundwater quality aspects}

Several groundwater samples were collected from wells penetrating the shallow and deep zones of the aquifer. The results of the chemical analysis indicate that groundwater salinity (TDS) varies in most of the samples from 150 to $200 \mathrm{mg} / \mathrm{l}$ in the shallow zone, while it varies from 130 to $200 \mathrm{mg} / 1$ in the deep zone.

\section{Hydraulic properties of the NSAS in the study area}

The hydraulic parameters of the NSAS are considered very important to evaluate the hydrogeological conditions of the study area, including the hydraulic conductivity, transmissivity and storativity.

Hydraulic conductivity $(\mathrm{K})$ describes the ease of flow of water into the pore spaces of the aquifer. Transmissivity is the product of hydraulic conductivity (K) and the aquifer saturated thickness, while storativity of the confined aquifer 
is the released water volume from storage per unit aquifer surface area per unit hydraulic head decline of groundwater (Kruseman, et al., 1994). The storativity varies due to the variation of particle shape, size, sorting, and cementation of the aquifer's matrix (Gutentag et al., 1984).

Transmissivity $(\mathrm{T})$ is a necessary parameter for evaluating the aquifer's potentiality. Gheorghe (1979) classified the aquifer's potentiality based on the transmissivity values as in Table 1 .

To estimate the hydraulic properties of the NSAS, pumping and recovery tests were conducted on seven selected wells. These production wells were distributed in the eastern, middle, and southwestern parts of the study area. The tested wells are: G, H, J, I, E, K and L. The NSAS is relatively homogeneous with semi-uniform thickness in the study area.

Generally, the long duration pumping tests and the recovery tests are necessary in estimating the hydraulic properties of aquifers. The analyses of the long rate pumping tests of the NSAS were done using Copper and Jacob method (1946) which is the suitable method according to the present aquifer conditions. Theis (1935) recovery method was also used.

The analysis of the constant rate pumping tests indicates that the transmissivity values vary from 495 to $7045 \mathrm{~m}^{2} / \mathrm{d}$ for the seven studied wells as illustrated in Table (2) and Figure (8), with average value of about $2704 \mathrm{~m}^{2} / \mathrm{d}$. The lithological changes play a role in changing transmissivity values between several areas. In addition, the presence of faults and fractures changes the transmissivity values. The eastern and southern zones at Sahl Baraka and the western side of Sahl Qaraween areas have high transmissivity values and hence are considered to be promising zones in the study area.
The hydraulic conductivity in the study area ranges between 1.3 and $18.5 \mathrm{~m} / \mathrm{d}$ for the studied wells with average of about $7.1 \mathrm{~m} / \mathrm{d}$. Due to limited number of monitoring wells during constantrate pumping tests for the new drilled wells, the storativity ( $\mathrm{S}$ ) was calculated by monitoring water level in one of the pumping wells. The storativity of the aquifer system within the study area was estimated as 0.0002 , that is similar to those published in earlier studies.

\section{Aquifer potentiality}

The potentiality of the aquifer to supply water in economic amounts depends on the quantity and quality of groundwater. The quantitative evaluation of the aquifer depends on the depth to groundwater, the saturated thickness, and the groundwater extraction rates. Additionally, the groundwater quality in terms of salinity and suitability for domestic and irrigation uses should also be considered.

Regarding the study area, the aquifer saturated thickness and groundwater salinity are uniform, but there is difference in potentiality and rates of groundwater extraction. The studied wells are flowing and non-flowing with relatively small depth to water (from ground surface). In terms of potentiality, the area could be divided into high and moderate potential areas.

The high potentiality zones include the middle and the eastern zones in Sahl Qaraween and Sahl Baraka. These zones are characterized by high productivity, presence of large number of flowing wells (water level varies from +110 to $+120 \mathrm{~m}$ above mean sea level), high transmissivity (above $500 \mathrm{~m}^{2} /$ day), high saturated thickness (more than $1500 \mathrm{~m}$ ) and relatively low extraction rates in addition to the low salinity ranges $(130-200 \mathrm{mg} / \mathrm{l})$.

The moderate potentiality zones are located in the western part of the study area in Lowa Sobieh,

TABLE 1. Aquifer potentiality according to transmissivity values (Gheorghe, 1979)

Aquifer potentiality

Transmissivity $\left(\mathbf{m}^{2} /\right.$ day $)$

\begin{tabular}{cc}
\hline High potential & $>500$ \\
Moderate potential & $50-500$ \\
Low potential & $5-50$ \\
Very low potential & $0.5-5$ \\
Negligibly potential & $<0.5$ \\
\hline
\end{tabular}

Egypt. J. Geo. Vol. 65 (2021) 


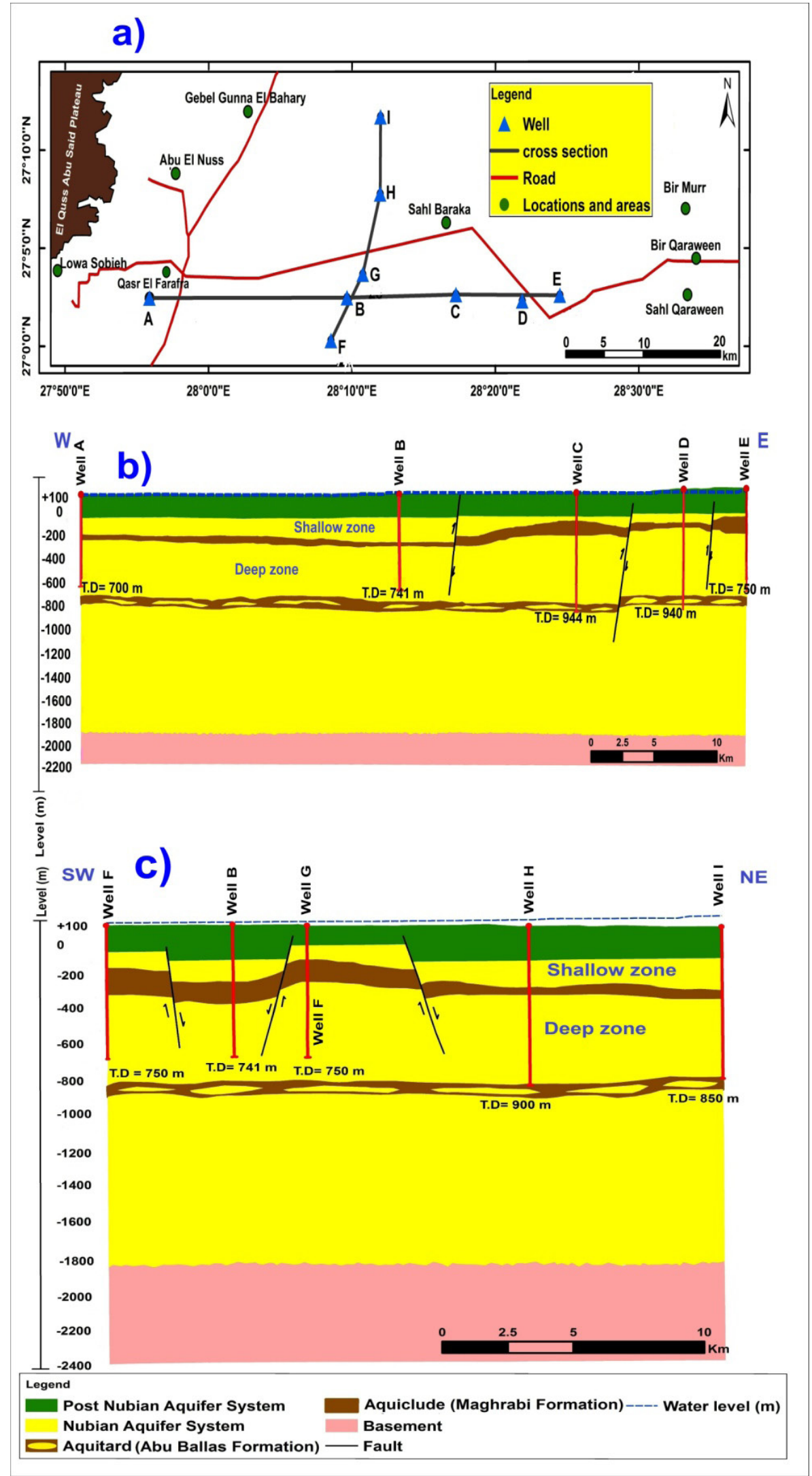

Fig. 6. a) Key map for the hydrogeological cross sections distribution in the study area, b) The E-W hydrogeological cross section in the study area, and c) The NE-SW hydrogeological cross section in the study area. 
TABLE 2. Values of hydraulic conductivity (K) and transmissivity $(T)$ of the studied wells in the study area

\begin{tabular}{lll}
\hline Well ID. & K (m/d) & T (m $\left.\mathbf{m}^{2} / \mathbf{d}\right)$ \\
\hline G & 2.9 & 1110 \\
H & 9.4 & 3600 \\
J & 5.9 & 2240 \\
I & 5.9 & 2260 \\
E & 18.5 & 7045 \\
K & 5.7 & 2178 \\
L & 1.3 & 495 \\
\hline
\end{tabular}

\begin{abstract}
Abu El Nuss, and Qasr El Farafra, where there are extensive groundwater extraction and relatively low transmissivity (less than $500 \mathrm{~m}^{2} /$ day). Within these areas, the water heads decreased due to the high extraction rates that recently reached about +80 m a.m.s.l, while it ranged between +150 and +152 m a.m.s.l. in 1965. Generally, the salinity does not exceed $200 \mathrm{mg} / \mathrm{l}$ except in few wells where possible over-pumping and thick clay lenses occur.
\end{abstract}

\section{Conclusions and Recommendations}

Conclusions

1) In the Egyptian Western Desert, especially in El Farafra Oasis, the NSAS could be considered the main source for groundwater supply needed for the development and land reclamation activities. The study area is located between latitudes $\left(26^{\circ} 59^{\prime}, 27^{\circ} 14^{\prime} \mathrm{N}\right)$ and longitudes $\left(27^{\circ} 49^{\prime} \mathrm{E}, 28^{\circ} 37^{\prime} \mathrm{E}\right)$ with a total area of about $2212 \mathrm{~km}^{2}$. Five subareas were selected for detailed hydrogeological investigation: Lowa Sobieh, Abu El Nuss, Qasr El Farafra, Sahl Baraka, and Sahl Qaraween.

2) This study aims to assess the hydrogeological characteristics of the main aquifers in the study area in view of the collected data from the new drilled wells in the years 2014, 2015 and 2016. To achieve these goals, several sources were used including the available geological and hydrogeological maps and logs of the drilled wells. The field investigations include among other activities well inventory of the shallow and deep wells, measuring of water level and piezometric head, collection and analysing of groundwater samples as well as conducting and analysing of pumping/ recovery tests on some selected wells.

3) Geologically, the surface of the study area is covered with formations varying in age from
Quaternary to Upper Cretaceous. The rock units are differentiated according to stratigraphic order from top to base as follows: Quaternary deposits (including sand dunes, sand sheets and playa deposits), Tertiary formations (including Farafra limestone, Esna Shale and Tarawan Chalk) and Khoman Formation which belongs to Upper Cretaceous.

4) The constructed two hydrogeological cross sections in E-W and NE-SW directions show the lateral and vertical extension of the Post Nubian Aquifer system (PNSAS) and the shallow and deep Nubian Sandstone Aquifer System (NSAS). The average thickness of PNSAS varies between $115-205 \mathrm{~m}$ while the thickness of the NSAS varies between 1725 $1875 \mathrm{~m}$. The cross sections also indicated the presence of clay formations separating the succession of the aquifer. The existing fault systems facilitate the hydraulic connection between the different zones of the aquifer system.

5) Based on the prepared piezometric water level contour map year 2019, the water level in the study area ranges between $+80 \mathrm{~m}$ and +120 $\mathrm{m}$ (above mean sea level), indicating a local groundwater flow direction from east to west. The main reason could be due to the increase in groundwater extraction within the study area and its environs where there is a lowering in groundwater level from $30-70 \mathrm{~m}$ in some parts of the old development areas.

6) The hydraulic parameters of the aquifer system were determined through the implementation of pumping/ recovery tests on selected seven newly drilled wells. The results of analysis of these tests indicates that the hydraulic conductivity of the NSAS in the study area varies between 1.3 and $18.5 \mathrm{~m} /$ day, the transmissivity varies between 495 and 7045

Egypt. J. Geo. Vol. 65 (2021) 

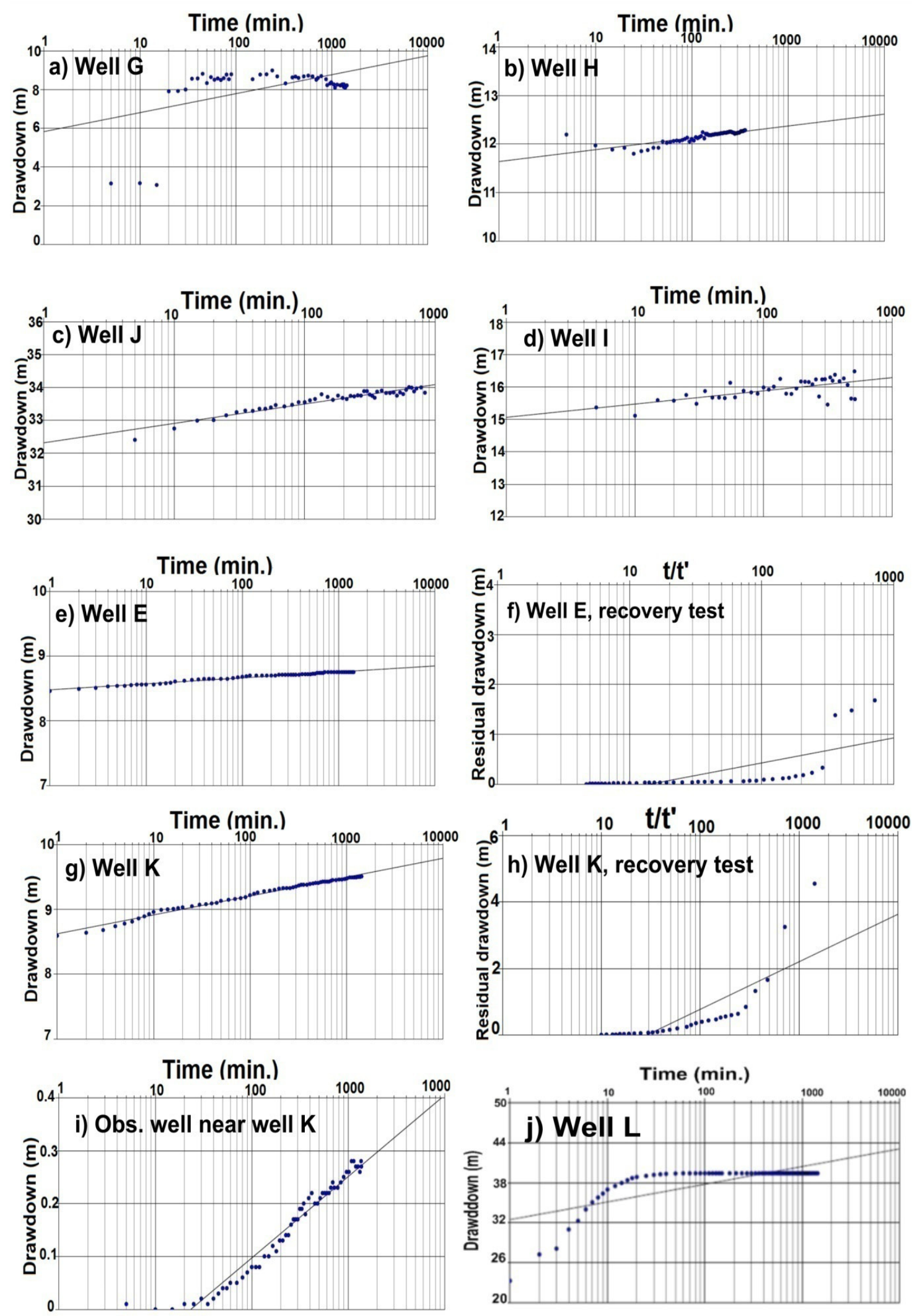

Fig. 7. Analyses of Time-Drawdown curves for the studied wells, where: a) Well G, b) Well H, c) Well J, d) Well I, e) Well E, f) Recovery test of well E, g) Well K, h) Recovery test of well K, i) Time-Drawdown curve of observation well near well $K$, and $j$ ) Time-Drawdown curve of well $L$. 


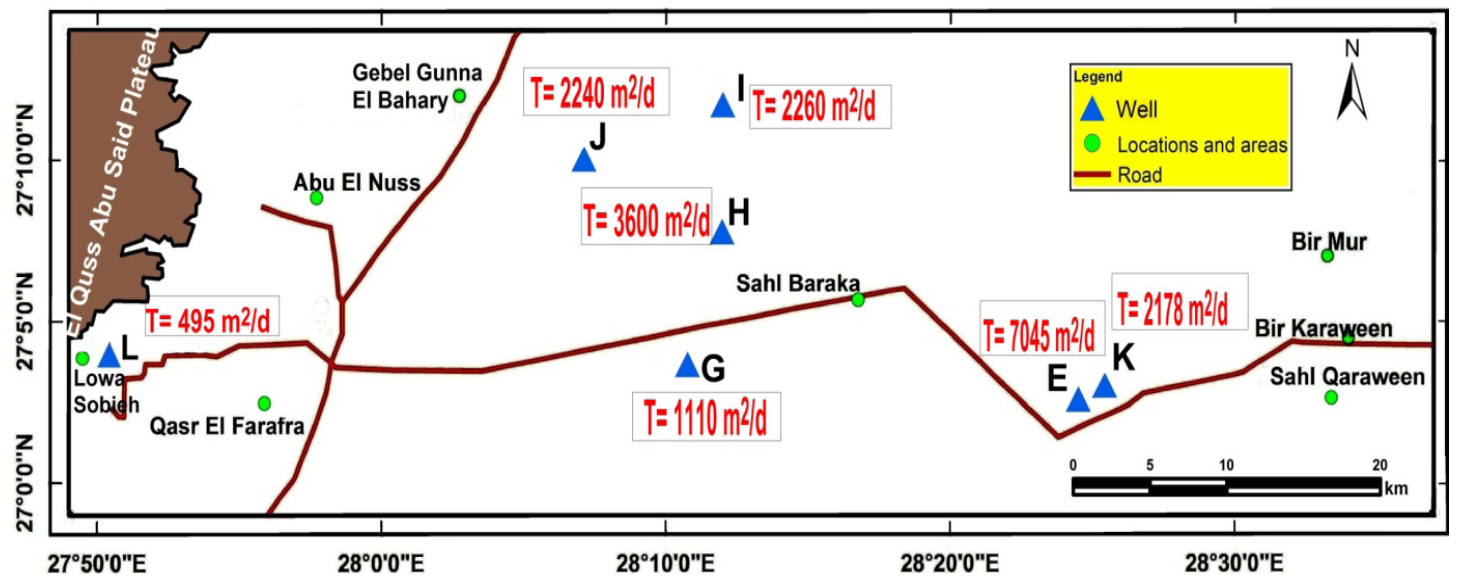

Fig. 8. Transmissivity values of the selected wells in the study area.

$\mathrm{m}^{2} /$ day, while the aquifer storativity reaches 0.0002 .

7) According to specific criteria regarding to hydrogeological parameters of the aquifer, the study area was classified into two zones: high groundwater potential zones restricted to the eastern and middle parts of the study area, and moderate groundwater potential zones in the western part of the study area at Lowa Sobieh, Abu El Nuss, and Qasr El Farafra areas.

\section{Recommendations}

On the view of the findings of the detailed hydrogeological study for El Farafra area, it is recommended to:

1) Propose groundwater development plan for El Farafra Oasis to protect the existing aquifer systems.

2) Implementation of groundwater monitoring wells in the new and old development areas to observe the changes in water level and groundwater quality.

3) Enforcement the well licensing system to control random drilling of new wells and over exploitation of the groundwater.

\section{Acknowledgments}

I would like to express my deep thanks to Prof. Dr. Ali Abdel-Motelib Ali, Dr. Hend Abu Salem and Prof. Dr. Akram Mohamed Fikry for their cooperation, continuous support and enthusiasm for help allover all steps of this work. Also, I would like to present my sincere thanks and great appreciation to Prof. Dr. Joseph Bushra Khalil, Prof. Dr. Sameh Sakr,
Prof. Dr. Gamal Abdel-Nasser and Dr. Heba AbdelAziz from the Research Institute for Groundwater (RIGW), National Water Research Center (NWRC) in Egypt for their helpful advices and support during the work stages.

\section{References}

Abdel Aziz, W. (1968) Geology of some Cretaceous and Eocene deposits in Farafra Oasis. M. Sc. Thesis, Fac. of Sci., Ain Shams Univ., Cairo.

Ali, M.T. (2004) Evaluation of groundwater resources of El Shiekh Marzouk area at Farafra Oasis in the western desert of Egypt. Ph. D. Thesis, Geol. Dep., Fac. of Sci., Menoufiya Univ., Egypt.

Barakat, M.G. and Abdel Hamid, M.L. (1974) Subsurface geology of Farafra Oasis, Western Desert, Eg. J. Geol, 17 (2): 97-110.

Bottcher, R. (1982) Die Abu Ballas Formation (Lingula Shale) (Apt) der Nubischen Gruppe Siidwest) Agyptens. Eine Beschreibung der Formation unter besonderer Beriicksichtigung der Paliontologie. Berliner Geowiss. Abh. 39, 145, Berlin.

Bottcher, R. (1985) Environmental model of the shallow marine Abu Ballas Formation (Aptian, Nubia Group) in South-Western Egypt, N. Jb. Geol. Paliont. Abh. 169: 261-283, Stuttgart.

Clemens, M., Khurelbaatar, G., Merz, R., Siebert, C., Afferden, M.V. and Rödiger, T. (2020) Groundwater protection under water scarcity; from regional risk assessment to local wastewater treatment solutions in Jordan. Sci. Total Environ., 706, 136066.

CONOCO Coral (1987) Geological Map of Farafra (1:500,000). Egyptian General Petroleum Corporation EGPC. Cairo. 
Cooper, H.H. and Jacob, C.E. (1946) A generalized graphical method for evaluating formation constants and summarizing well field history, Americ. Geoph. Union.

El-Shayeb, H., El-Hemaly, I.A., Abdel Aal, E., Saleh, A., Khashaba, A., Odah, H. and Mostafa, R. (2013) Magnetization of three Nubia Sandstone formations from Central Western Desert of Egypt, NRIAG J. Astron. and Geoph., 2: 77-87.

Elshiekh, A.E. (2015) Mitigation of groundwater level deterioration of the Nubian Sandstone aquifer in Farafra Oasis, Western Desert, Egypt, Environ. Earth. Sci., 74: 2351-2367.

Gheorhge, A. (1979) Processing and synthesis of hydrogeological data. Abacus press, 390.

Gutentag, E. D, Heimes, F.J, Krothe, N.C, Luckey, R.R. and Weeks, J.B. (1984) Geohydrology of the High Plains aquifer in parts of Colorado, Kansas, Nebraska, New Mexico, Oklahoma, South Dakota, and Wyoming. U.S. Geol. Surv. Prof. Pap., 1400-B, 63 .

Hamad, M.H.M. (2004) Subsurface geological, hydrogeological and hydrogeochemical studies on the inter-stratal waters in Farafra Oasis, Western Desert, A.R. Egypt. M.Sc. Thesis, Geol. Dep., Fac. of Sci., Cairo Univ.

Heinl, M. and Brinkmann, P.J. (1989) A groundwater model of the Nubianaquifersystem, Hydrol.Sci.J.,34 (4): 425-447, DOI: 10.1080/02626668909491350.

Keesari, T., Kulkarni, U.P., Deodhar, P., Ramanjaneyulu, P.S., Sanjukta, A.K. and Kumar, U.S. (2014) Geochemical characterization of groundwater from an arid region in India. Environ. Earth Sci., 71, (11): 4869-4888.

Klitzsch, E. (1978) Geologische Bearbeitung SudwestAgyptens. Programm und Ergebnisse. Geol. Rundsch., 67, (2): 509-520.

Klitzsch and Lejal-Nicol, A. (1984) Flora and fauna from strata in Southern Egypt and Northern Sudan (Nubia and surrounding areas), Berliner Geowiss. Abh. 50, 47-79.

Kruseman, G.P., de Ridder, N.A. and Verweij, J.M. (1994) "Analysis and evaluation of pumping test data", ILRI, The Netherlands.

Llamas, M.R. and Martinez-Santos, P. (2005) Intensive groundwater use: Silent revolution and potential source of social conflicts. J. Water Resour. Plan. Manag.
Nassar, T. H. (2005) Geology and Groundwater Assessment of Farafra Oasis, Western Desert, Egypt. M.Sc. Thesis, Geol. Dep., Fac. of Sci., Cairo Univ.

Omar, M.M and Moussa, A.M.A. (2016) Water management in Egypt for facing the future challenges, J. Adv. Res., 7: 403-412.

Re, V and Zuppi, G.M. (2011) Influence of precipitation and deep saline groundwater on the hydrological systems of Mediterranean coastal plains: a general overview. Hydrol. Sci. J., 56, (6): 966-980.

RIGW/ASRT (2016) Hydrogeologic map of FarafraBahariya (scale 1:500,000), with its explanatory note for the Academy of Scientific Research. Joint project between RIGW and ASRT.

Salem, A.A.A. (2002) Hydrogeological studies on the Nubia Sandstone Aquifer in Bahariya and Farafra depressions, Western Desert, Egypt. Ph.D. Thesis, Geol. Dep., Fac.of Sci., Ain Shams Univ., Cairo.

Schrank, E. (1982) Kretazische Pollen und Sporen aus dem Nubischen Sandstein des Dakhla-Beckens (Agypten). (Beitrage zur Palaontologie Agyptens, Nr. 3). Berliner Geowiss. Abh. 40: 87-109.

Theis, C.V. (1935) The relation between the lowering of the piezometric surface and the rate and duration of discharge of a well using groundwater storage, $\mathrm{Am}$. Geophys. Union Trans., 16: 519-524.

Wang, G. and Cheng, G. (1999) Water resource development and its influence on the environment in arid areas of China-the case of the Hei River basin, J. Arid Environ., 43: 121-131.

Zaghloul, E.A. (1983) Geology of Abu MinqarFarafra- Ain Dallah stretch. Western Desert. Egypt. Ph. D. Thesis, Geol. Dep. Fac. of Sci., Cairo Univ.

Web Resources: http://newvalley.gov.eg/Pages/ GovernerHome.aspx 


\section{الضصرائص اللزبيةروجيولوجية للجزء الثمالي الثرقي من واحة الفرافرة،

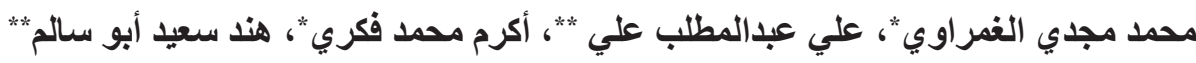

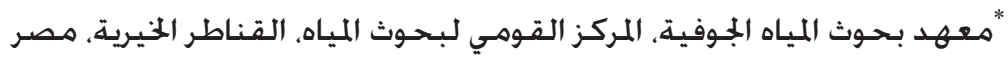

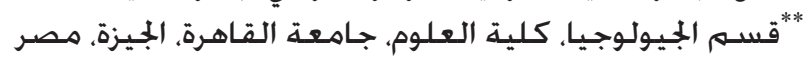

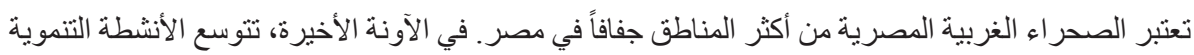

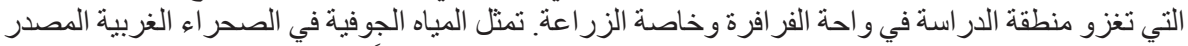

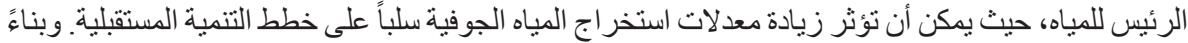

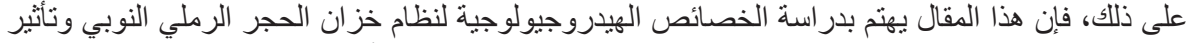

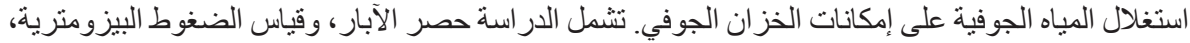

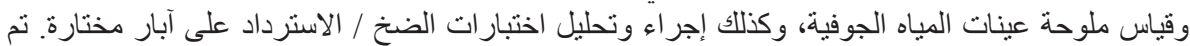

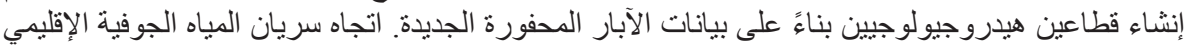

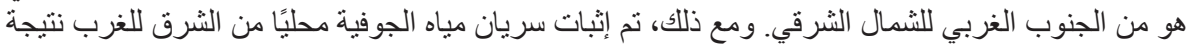

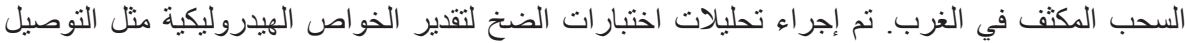

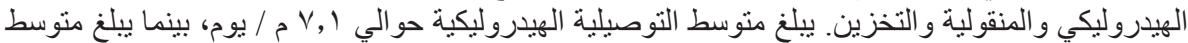

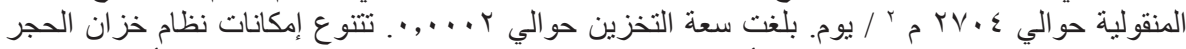

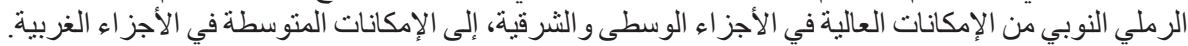
يوصي بخطة تتمية للمياه الجوفية لتجنب تدهور نظام خزان الإن الحجر الرملي النوبي في العقود القادمة. 